\title{
A Study of CFO and CEO Attributes: Cash and Operating Cycles as Determinant Measures of Success
}

\author{
Amy Fairfield \\ Bellarmine University
}

\begin{abstract}
The chief executive officer (CEO) is the face of an organization. Nonetheless, since the Sarbanes-Oxley Act of 2002, the importance of the chief financial officer (CFO) has increased. This study examines similar characteristics of the CFO and CEO against various firm performance metrics, with emphasis on cash and operating cycles. The theory of cash management emphasizes the importance of cash flow management as a means for a company to maintain its solvency--a responsibility primarily belonging to the CFO. More CFO characteristics showed significance than CEO characteristics, indicating more firm performance success contributed by the CFO. There is a growing literature stream on CFOs, and with increased accountability being placed on the CFO, more will need to be known about this position and the characteristics that contribute to a successful CFO.
\end{abstract}

Keywords: cash cycle, operating cycle, CEO, CFO, firm performance

\section{INTRODUCTION}

Since the Sarbanes-Oxley Act of 2002 (SOX), the importance of the chief financial officer (CFO) position has dramatically increased, as evidenced by the signatory requirement on Securities and Exchange Commission (SEC) quarterly and annual reports (Alkhafaji, 2007; Schminke et al., 2007). Nonetheless, CFOs have been receiving more attention (Barua, Davidson, Rama, \& Thiruvadi, 2010; Datta \& IskandarDatta, 2014; Geiger \& North, 2006) and have come under greater scrutiny. The investing public expects the CFO to have knowledge of and control over the entire finance and accounting functions of the company and to uphold the fiduciary responsibility when reporting financial information to the SEC. It is imperative to understand how the CFO effectively and efficiently manages the finance functions on behalf of the company and to identify the attributes needed for success.

The purpose of this research is to analyze CFO attributes to determine whether there is some degree of success to be attained by the CFO, as measured by financial firm performance, including cash cycle (CC) and operating cycle (OC). A great deal of literature pertains to the role of the chief executive officer (CEO; Zhang \& Wiersema, 2009), and although the CEO is ultimately responsible for an organization, the role of CFO has seen increasing relevance (Florackis \& Sainani, 2018; Zorn, 2004). Often considered the number two position, behind the CEO (Buchheit, Reitenga, Ruch, \& Street, 2019), a CFO is primarily responsible for financial reporting; has oversight of corporate treasury; and as a member of the top management team, must think strategically to make sound business decisions for the organization and its stakeholders.

In this study, I looked at the relationship between specific CFO attributes and financial information. The CFO attributes are age, gender, professional degree (e.g., Master of Business Administration), certified 
public accountant (CPA) designation, industry experience, total compensation, and tenure at current firm. The specific financial information explored are profitability ratios (return on assets [ROA] and return on equity [ROE]), acquisitions, investments, cost of equity, and cycle measures (CC and $\mathrm{OC}$ ).

For both $\mathrm{CC}$ and $\mathrm{OC}$ as well as acquisitions and investment, I used the natural log to eliminate outliers. All models were checked with winsorized data, with supporting results. In addition, I used only positive observations for acquisitions and cost of equity. Also, to ascertain whether the CFO performs better than the CEO, I included the same attributes (age, gender, professional degree, CPA designation, industry experience, total compensation, and tenure at current firm) for the CEO as control variables. I also included firm-specific control variables that impact financial performance.

$\mathrm{CC}$ and OC are used to assess company success (Groth, 1992). Previous research has utilized CC as the dependent variable (Jalal \& Khaksari, 2020; Lai, 2006; Palombini \& Nakamura, 2012; Rutgersson \& Uddenberg, 2010), lauding the success of the company but there has been no direct measure for the efforts of the CFO or CEO and their contributions toward the success. With more attention being given to the role of CFOs and with the elevation of their accountability, there is an opportunity to fill a gap explaining the development of the CFO's role and the accompanying success that should follow, especially on behalf of the company's stakeholders.

All CFOs have a fiduciary responsibility to their companies' stakeholders. One of the most important functions of a CFO is to keep the company solvent. This is accomplished by maintaining sufficient cash flow. The theory of cash management emphasizes the importance of cash flow management as a means for a company to maintain its solvency (Gitman, Moses, \& White, 1979). Cash management has evolved from the study of cash collections and cash disbursements and the concept of maintaining the appropriate balance of cash. As the study of cash management gained practical acceptance, $\mathrm{CC}$ was developed as a performance measure. "Cash cycle is an additive measure of the number of days funds are committed to inventories and receivables less the number of days payments are deferred to suppliers." (Johnson \& Soenen, 2003, p. 366). As a cash management tool, $\mathrm{CC}$ is instrumental in serving as an explanation for other financial ratios (Kpodoh, 2010; Rutgersson \& Uddenberg, 2010).

I used a post-SOX time period, 2003 through 2016, for this study. The model parameters were estimated by ordinary least squares regression using panel data. I tested the impact of CFO and CEO attributes on company financial data. The results were analyzed to determine whether a reliable conclusion could be reached about the success of a CFO.

The implications of my study are three-fold. First, for the position of the CFO as well as board members; board members should be aware of a CFO's previous success as they add someone to the CFO position in the C-Suite. Second, for analysts as they determine firm value and disseminate their opinions to the investing public, who seek to do further analysis with the information found in financial statements and are looking for additional metrics to make more informed investment decisions (John, 2001). Third, regarding the abusive power, particularly by large firms, including manipulating CC or OC for their own benefit, especially in an economic downturn (Trent, 2019).

Grounded in the theory of finance, this research, supported by empirical findings, will contribute to the growing strand of literature focusing on the CFO. Specifically relying on the theory of cash management (Gitman, Moses, \& White, 1979), the analysis included how CFOs manage the acquisition and utilization of funds for their organizations, and the use of both $\mathrm{CC}$ and $\mathrm{OC}$ as measures for CFO success. Therefore, the research will also contribute to the use of $\mathrm{CC}$ and $\mathrm{OC}$, especially as they relate to the success of a CFO. Prior research has indicated working capital improvement (Filbeck, Krueger, \& Preece, 2007), success for companies (Jalal \& Khaksari, 2020), and success for the supply chain (Duman \& Sawathanon, 2009; Lopatta, Böttcher, \& Jaeschke, 2018).

In addition, aspiring CFOs who are planning their careers, may begin during graduate or executive education. Accordingly, this study could contribute to academia, for the development of finance and accounting curriculum as well as career development. Extending graduate education to future CFOs, at the appropriate time in their career (given their age and experience) will benefit the CFO as well as their firm and its stakeholders. 


\section{THEORY}

The theory of finance is a theoretical framework of the subject matter (Fama \& Miller, 1972). The theory of finance provides in-depth fundamental building blocks, encompassing many other economic theories. The theory of choice involves one's personal preferences, and in the field of finance, the problem arises as to how individuals' financial resources are allocated over time (Fama \& Miller, 1972). The theory of finance addresses financial policy and investment decisions in the corporate world. Thus, in the context of an organization, decisions are not made by individuals; instead, the day-to-day operational decisionmaking is entrusted to professional managers - the agency relationship, supported by agency theory (Jensen \& Meckling, 1976).

Fundamentally, managers are to operate such that they maximize profit in every unit of time and, subsequently, maximize net return to shareholders. Over the last several decades, the role of CFO has been elevated to managing shareholders and stock prices (Zorn, 2004) and since the enactment of SOX, a higher level of financial accountability. The CFOs must have the knowledge (and traits) to serve in their capacity as the manager who has primary responsibility for the accounting and finance functions of the firm (Baxter \& Chua, 2008; Bourdieu, 1977; Büttner, Schäffer, Strauss, \& Zander, 2013; Granlund \& Lukka, 1998).

Hambrick and Mason (1984) proposed upper echelons theory to offer the foundation for further research into the link between managerial backgrounds and organizational outcomes. Their study suggested the emphasis should be on observable managerial characteristics (e.g., age, functional track, professional degree).

The purpose of this paper is to analyze the relationship between CFO attributes and CFO success, as shown in Figure 1.

FIGURE 1

\section{CONCEPTUAL FRAMEWORK OF MODEL}

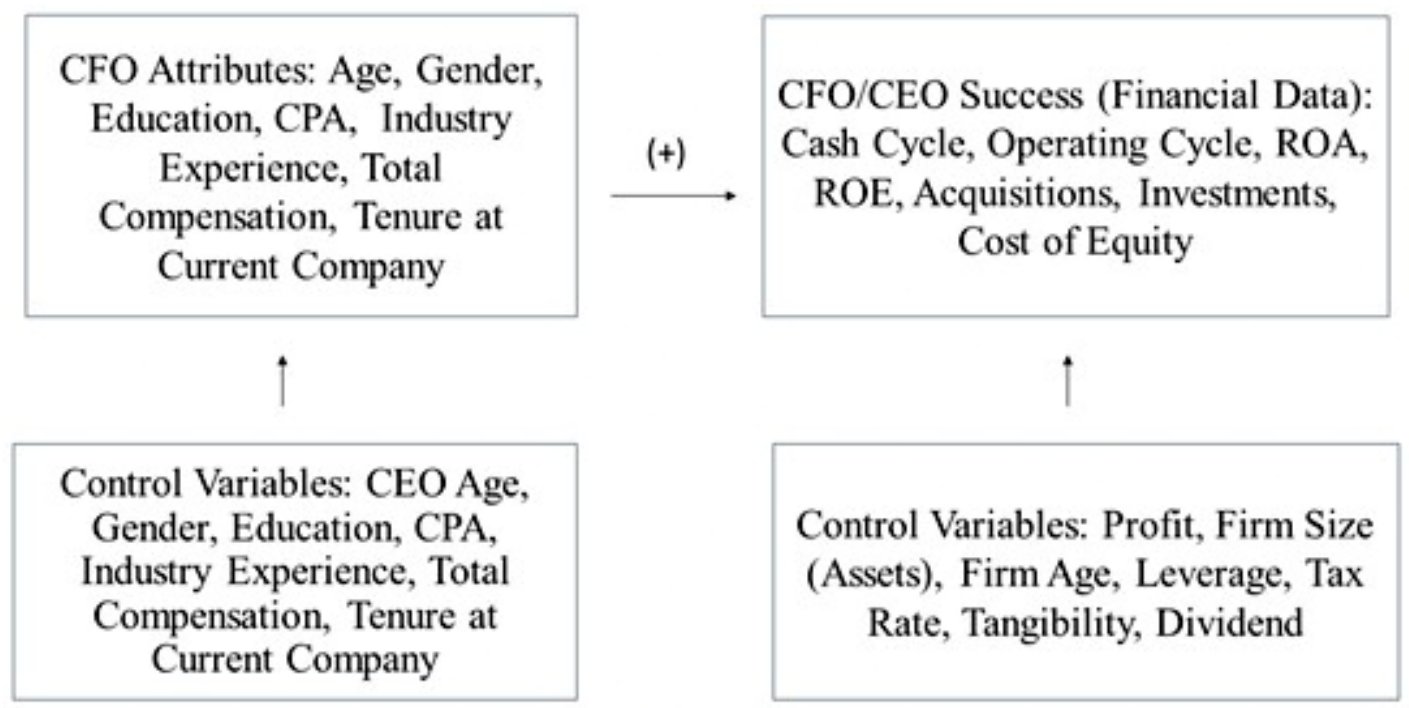

This model delineates the conceptual framework of the model I used in the study. Chief Financial Officer (CFO) Success is the dependent variable, operationalized by numerous firm performance metrics. Control variables were added for the chief executive officer (CEO). CFO attributes are the independent variables. CFO attributes will positively impact CFO success. Control variables (that affect financial measurements) were also added. CPA represents certified public account; ROA represents return on assets; ROE represents return on equity. 


\section{LITERATURE REVIEW AND HYPOTHESES DEVELOPMENT}

The operationalized variables used for CFO success are described in the following paragraphs, beginning with $\mathrm{CC}$. The imbalance of outflows and inflows of cash to a firm causes liquidity issues. The concept of CC was introduced by Gitman (1974). Richards and Laughlin (1980) suggested that the concept of OC (the sum of inventory cycle and receivable cycle) became deficient due to ignoring the time dimension of current liability commitments which is useful for cash flow measurement and liquidity requirement of the firm. Thus, the cash conversion cycle (CC) was operationalized by Richards and Laughlin (1980) to show the amount of time between a company receiving payment from its customers and when the company must pay its suppliers. The purpose of this concept is to improve working capital management.

One factor critical to a company's success is its ability to effectively assess the health of its working capital cash flow generation (John, 2001). Previous research has shown that CC is better at diagnosing the health of a company's working capital cash flows. Although the current ratio seems to be a more popular financial tool in liquidity analysis, cash (conversion) cycle is a better predictor of cash flow (John, 2001). In addition, as a transactional measure that captures both the current assets and current liabilities of efficient management of working capital, it is better to use CC (Jalal \& Khaksari, 2020). Maintaining a healthy cash rate is a treasury function, falling under the auspices of the CFO. A CFO would be more efficient, and more successful, if the CC were low. A shorter CC indicates better managerial efficiency, and as such, should serve as a proxy to indicate CFO success.

The market value rule applies when management makes investment and financing decisions based on the market and market prices. (Fama \& Miller, 1972). Under the ordinary theory of production, once the production plan is in place, the objective is to maximize net returns to shareholders. (Fama \& Miller, 1972). In the ordinary theory of the firm, this is referred to as profit and profit maximization (Fama \& Miller, 1972). Profitability can be measured by ROA and ROE.

Fundamental financial analysis is an essential step in the investment analysis process. Both ROA and ROE are strong profitability ratios, indicating how well a company utilizes its assets and shareholders' equity, respectively. These two commonly used ratios are utilized to measure a firm's strength.

It is often common practice to evaluate and measure the success of managers (CFOs and CEOs) based on financial metrics of a firm. These metrics often take the form of financial ratios. Financial ratio analysis is an integral part of financial analysis. There are five categories of financial ratios. For this analysis, I focused on one: profitability ratios, specifically, ROA and ROE. Both ROA and ROE have been used extensively in research (Banerjee \& Kaya, 2016; Pettus, 2006) as they are indicative of a healthy company. Much like ROA and ROE indicate health and success of a firm, ROA and ROE will serve as proxies for CFO success.

Cash flows are the stream of earnings generated by a firm. Cash flow creation is in the context of cash earnings less accounting adjustments, for example, depreciation (Fama \& Miller, 1972). The components of cash flow, sources and uses of funds, are generated by the firm's production and investment decisions, including acquisitions and capital expenditures (Fama \& Miller, 1972). An increase in cash flow will provide additional funds. I predicted that additional funds would enable an increase in the number of acquisitions and/or an increase in the number of investments (capital expenditures). Value-added acquisitions and profitable investments will lead to greater success for a CFO.

The risk-return trade-off is a concept that beguiles (or worries) investors; it is a relative measure of one's portfolio, determined by one's parameters (Fama \& Miller, 1972). The risk-return concept is also valid for the market as a whole. The pricing equation shows the market price per unit of expected value and the market price per unit of risk are the same for all shares (Fama \& Miller, 1972).

Under the risk class model, based on a firm's operating (production-investment) decisions, the firm's total market value at any point in time is independent of its financing (Fama \& Miller, 1972). The wealth of current shareholders is the same as the wealth of current bondholders (Fama \& Miller, 1972). Thus, operating and financing decisions can be made independently (Fama \& Miller, 1972). The weighted average cost of capital (WACC) is used to determine a company's cost of financing, either through borrowing or 
raising funds; WACC represents the effects of financing decisions on the firm's shareholders and bondholders. However, many companies do not (perhaps should not) use debt financing (Beneda, 2003; Elkhal, 2019; Hull, 2011; Pagano \& Stout, 2004). In the absence of sufficient observations including debt, I used cost of equity in the model. A higher cost of equity means the cost of financing will be higher. Thus, I predicted a lower cost of equity will lead to greater success for a CFO.

The CFO attributes chosen for this analysis are age, gender, professional degree, CPA designation, industry experience, total compensation, and tenure at current firm. These CFO attributes have been utilized in previous literature with supported empirical evidence of their efficacy (Barua et al., 2010; Datta \& Iskandar-Datta, 2014; Geiger \& North, 2006; Sellers, Fogarty, \& Parker, 2016; Zhang \& Wiersema, 2009). Many of these characteristics have roots in Spence's (1973) seminal signaling theory model. Education is the signal. Age and gender are included as indices. The CFO attributes are explanatory variables for the response variables representing CFO success. The hypotheses that follow were developed to test and explain the relationships among these variables.

An older CFO will likely bring more experience to the office. The experience could come from outside the company, within the company, or perhaps even from an area other than accounting or finance. Regardless, an older CFO likely has the benefit of knowing the circumstances that precipitated the need for SOX.

Under the premise of SOX requiring CEOs and CFOs to certify their companies' financial statements, Huang, Rose-Green, and Lee (2012) examined the relationship between CEO age and the financial reporting quality of their firms. Relying on prior research, Huang et al. (2012) hypothesized that older individuals are more ethical and conservative than younger individuals and that they would less likely be involved in aggressive earnings management. Their results suggested that older CEOs are associated with higher-quality financial reporting (Huang et al., 2012). Similarly, in their research on the influence of individual executives on corporate financial reporting, Plöckinger, Aschauer, Hiebl, and Rohatschek (2016) noted that older CEOs are less often involved in fraudulent actions. Connecting age and experience with firm performance, Rambe and Mangara (2016) analyzed the impact of integrated reporting ratings (IRR), the CEO's age, and the individual's tenure as CEO on the company's share price. Their findings showed that share price of a company tends to increase with an increase in IRR, CEO age, and CEO years of experience (Rambe \& Mangara, 2016). This leads to the argument that an older CFO will have more experience to manage the financial operations of a firm. Formally stated, my hypothesis is:

\section{$\boldsymbol{H}_{1}$ : An older $\mathrm{CFO}$ will have more favorable firm performance outcomes.}

By favorable outcomes, I mean lower CC and OC, higher ROA, higher ROE, more acquisitions, higher capital expenditures, and lower cost of equity.

A conservative financial decision made will not necessarily produce the best outcome. Making decisions requires risk assessment. In terms of risk taking, one can be more, or less, risk averse. There are noted gender differences in risk assessment abilities which may contribute to the understanding of a CFO's success.

Following Halpern's (1992) notion that studying gender differences can contribute to theoretical advances, Byrnes, Miller, and Schafer (1999) performed a meta-analysis to compare risk-taking tendencies between males and females; they discovered, in general terms, that males are more likely to take risks than females. Regarding financial decision-making by professionally trained investors, Olsen and Cox (2001) found that female investors weight risk attributes more heavily than male investors. In addition, they found that women will underscore risk reduction more than men when constructing portfolios (Olsen \& Cox, 2001). In their research on the influence of individual executives on corporate financial reporting, Plöckinger et al. (2016) noted that female executives tend to report more conservatively and typically display more risk-averse accounting behavior than their male counterparts. Huang and Kisgen (2013) analyzed corporate financial and investment decisions made by both female and male executives. They found that male executives undertake more acquisitions and issue debt more often than female executives. They further report that acquisitions made by firms with male executives have announcement returns 
approximately $2 \%$ lower than those made by female executive firms. By comparison, Huang and Kisgen (2013) surmise that male executives demonstrate overconfidence in their decision-making whereas female executives display more caution. This leads to the argument that a male CFO will be more aggressive in their decision-making. Formally stated, my hypothesis is:

\section{$\boldsymbol{H}_{2}:$ A male CFO will have more favorable firm performance outcomes.}

According to Spence's (1973) signaling theory, education is the signal to the employment market. Plöckinger et al. (2016) noted that more educated CEOs seem to be less often involved in fraudulent actions. Executives having a Master of Business Administration (MBA) degree tend to be more conservative in making their earnings forecasts, are more likely to disclose financial information, and report higher quality earnings (Plöckinger et al., 2016). In addition, CFOs with an MBA degree or CPA certification are less often involved in restatements than CFOs without such degrees (Plöckinger et al., 2016). Depending on their aspirations, CFOs can focus their expertise on the accounting field (CPA) or pursue a more extensive business degree (MBA). The business degree will assist a CFO with strategic decision-making. However, given the strict requirements imposed by SOX, it seems prudent for firms to seek CFOs with specialized accounting skills. In fact, O'Sullivan (2004) reported that after SOX in 2002, executive recruiters favored CFO candidates with a CPA. However, since then, Chahyadi and Abusalim (2011) found that CFOs in large firms have different education characteristics than CFOs in medium-sized firms. Their results showed that large firms rate CFOs with more general skills (MBA) more highly than CFOs with a Master of Accounting or CPA certification (Chahyadi \& Abusalim, 2011). This leads to the argument that a CFO with a professional degree will have the knowledge to utilize better financial tools, and a CFO holding a CPA license will have expertise in the accounting function. Formally stated, my hypotheses are:

\section{$\boldsymbol{H}_{3}$ : A CFO with a professional degree (e.g., MBA) will have more favorable firm performance outcomes.}

\section{$\boldsymbol{H}_{4}$ : A CFO holding a CPA certification will have more favorable firm performance outcomes.}

It was noted previously that with age comes experience, and that experience can be acquired in different places. Aier, Comprix, Gunlock, and Lee (2005) analyzed characteristics of CFOs associated with accounting restatements. One of their variables is experience at another firm; their results showed that companies having CFOs with this kind of experience are less likely to restate earnings Aier et al., 2005). Cohen and Dean (2005) operationalized top management team legitimacy by using two types of experience: top managers with industry experience and top managers with top management team experience; they reasoned that qualified and experienced top managers would have choices as to where they could work. Both types of experience, along with age, were significant, with prior industry experience and age having the greatest effect (Cohen \& Dean, 2005). Another facet of experience is the extrinsic reward of compensation. Chahyadi and Abusalim (2011) analyzed education and experience of CFOs to ascertain if these variables affect CFO compensation. The findings indicated that a CFO's tenure at his or her current company and previous experience as a CFO at another company contribute to the CFO's compensation (Chahyadi \& Abusalim, 2011). In addition, Chahyadi and Abusalim (2011) found that older and more experienced CFOs are more highly compensated. This leads to the argument that having more experience in an industry will provide a CFO with more knowledge to manage the financial operations of their firm. Formally stated, my hypothesis is:

\section{$\boldsymbol{H}_{5}:$ A CFO with industry experience will have more favorable firm performance outcomes.}

Extending from the last variable, I segue to a discussion on compensation. Holden (2005) analyzed the original incentive schemes developed by Du Pont and General Motors in the 1920s, connecting executive compensation to stock prices. In the 1990s, the use of stock options greatly increased; this was seen as a strategic move, to align the incentives of managers with those of stockholders (Holden, 2005). But by the 
early 2000s, these schemes were being criticized for encouraging excessive risk-taking, short-term orientation, and even tempting managers to commit fraud in order to ensure a high stock price at the time of exercise (Holden, 2005). Grossman and Hoskisson (1998) agreed that incentive plans expose executives to risk and imbue a short-term bias on their decision-making processes. They suggested developing an incentive plan that is based on the applicable performance metrics (be it accounting performance or stock price performance), that aligns with the firm's strategic plan, and considers the timing of rewards (Grossman \& Hoskisson, 1998). To be more specific, Nourayi and Mintz (2008) tested the association between CEO tenure, compensation, and firm's performance. They used both cash compensation and total compensation as the dependent variables (Nourayi and Mintz, 2008). For performance measures, they utilize total one-year shareholder return on common stock and ROA (Nourayi and Mintz, 2008). Their findings revealed that compensation of less experienced CEOs tends to be influenced by firm performance; they also found that performance measures are positively correlated with cash compensation and negatively with total compensation (Nourayi and Mintz, 2008). Feng, Ge, Luo, and Shevlin (2011) explored why CFOs become involved in material accounting manipulations. They discovered that while CFOs bear substantial legal costs when involved in accounting manipulations, these CFOs have similar equity incentives to the CFOs of matched non-manipulation firms (Feng et al., 2011). However, CEOs of manipulation firms have higher equity incentives and more power than CEOs of matched firms (Feng et al., 2011). Given that combination, they suggested their findings are consistent with the explanation that CFOs are involved in material accounting manipulations because they succumb to pressure from CEOs, rather than because they seek immediate personal financial benefit from their equity incentives (Feng et al., 2011). Balsam, Irani, and Yin (2012) analyzed the effect of job complexity, firm performance, and CFO-specific performance, on CFO compensation. Firm performance was proxied by accounting and stock market returns (Balsam et al., 2012). CFO-specific performance is measured on two dimensions: ability to meet or beat earnings targets and the use of earnings and/or expectations management in achieving that goal (Balsam et al., 2012). Their results suggested that overall firm performance affects both CFO salary and bonus, while CFOspecific performance affects CFO bonus (Balsam et al., 2012). More specifically, they found that CFOs are not only rewarded when their firms meet or beat earnings targets, but they receive incremental rewards for managing earnings and/or expectations to allow their firms to meet or just beat those targets (Balsam et al., 2012).

As members of the top management team, where strategic planning takes place, CFOs know the mission of the company, understand the detrimental ramifications of SOX, and would have access to provide pertinent information for establishing compensation plans for executives. This leads to the argument that a CFO with higher total compensation will work not only to maintain their current position but to preserve the value of any restricted stock or stock options. Formally stated, my hypothesis is:

\section{$\boldsymbol{H}_{6}:$ A CFO with higher compensation will have more favorable firm performance outcomes.}

Huang et al. (2012) used tenure to control for any confounding effects of experience on age and found the result for tenure to be insignificant. However, while examining the role of education and experience in CFO career and compensation, Chahyadi and Abusalim (2011) found that a CFO's tenure at his or her current company consistently dominated the measures of CFOs' education and experience to explain CFO compensation. In addition, Allgood and Farrell (2000) evaluated the effect of CEO tenure on the relationship between firm performance and forced turnover. Their findings indicated that performanceforced turnover is conditional on CEO tenure, noting the difference between an inside CEO, an outside CEO, and a founder (Allgood \& Farrell, 2000). Dikolli, Mayew, and Nanda (2014) also found in their study of CEO turnover that CEO survival is associated with superior firm performance. This leads to the argument that a CFO who has been with his or her current firm for a longer period of time will have insight to manage the finance function more effectively. Formally stated, my hypothesis is:

H7: A CFO with longer tenure at his or her current firm will have more favorable firm performance outcomes. 
Having hypothesized about each of the variables and the relationship between them, next is the methodology section to discuss design and the model. The CFO attributes will be regressed on each of the firm financial performance metrics. Also included in the model are control variables matched to the CFO attributes and control variables that affect the firm financial performance metrics.

\section{METHODOLOGY}

In this section, I present my research design. First, I discuss how I captured the key construct in my study, that is, CFO success. Second, I discuss how I proxied for CFO attributes. Then I present the model to test my hypothesis on CFO success.

\section{Measures}

\section{Chief Financial Officer Success}

There are seven dependent variables used as proxies for CFO success: CC, OC, ROA, ROE, acquisitions, investments, and cost of equity. For both $\mathrm{CC}$ and $\mathrm{OC}$ as well as acquisitions and investment, I used the natural log to eliminate outliers. All models were checked with winsorized data, with supporting results. In addition, I used only positive observations for acquisitions and cost of equity. Following Jalal and Khaksari (2020) and based on the effect they have on the dependent variables, the following control variables were included in the model: the natural $\log$ of total assets, firm age, leverage, firm tax rate, tangibility, and dividends. All control variables were lagged one year. Annual data was used. Thus, yearend fixed effects were included, as were industry-fixed effects. See Appendix A for variable definitions.

\section{Chief Financial Officer Attributes}

The independent variables are the proxies used for CFO attributes: age, gender, professional degree, CPA designation, industry experience, total compensation, and tenure at current job. Many of these variables are included in Spence's (1972) signaling theory. To test whether a CFO has more (less) success than the CEO, similar variables are included in the model as controls. See Appendix A for variable definitions.

\section{Data Analysis}

Empirical Model

Using panel data, ordinary least squares regression was used to examine the impact of CFO attributes on CFO success.

CFO Success $=$ Intercept + Beta*CFO Attributes + CEO Attributes + Control Variables + error

The following regression equation was tested to determine if there is any statistical significance to explain the relationship between CFO attributes and CFO success. In addition, I tested whether the CFO attributes contribute more to the success of the firm compared to the $\mathrm{CEO}$ attributes.

CFO Success $=\lambda_{0}+\lambda_{1} *$ CFOage $+\lambda_{2} *$ CFOgender $+\lambda_{3} *$ CFOprofdeg $+\lambda_{4} *$ CFOcpa $+\lambda_{5} *$ CFOindusexp

$+\lambda_{6} *$ CFOtotcomp $+\lambda_{7} *$ CFOtenure $+\lambda_{8} *$ CEOage $+\lambda_{9} *$ CEOgender $+\lambda_{10} *$ CEOprofdeg $+\lambda_{11} *$ CEOcpa

$+\lambda_{12} *$ CEOindusexp $+\lambda_{13} *$ CEOtotcomp $+\lambda_{14} *$ CEOtenure $+\lambda_{15} *$ profit $+\lambda_{16} *$ lnassets $+\lambda_{17} *$ firmage

$+\lambda_{18} *$ lev $+\lambda_{19} *$ taxrate $+\lambda_{20} *$ tangib $+\lambda_{21} *$ div + error

where CFO success is measured separately by $\mathrm{CC}, \mathrm{OC}, \mathrm{ROA}, \mathrm{ROE}$, acquisitions, investments, and cost of equity; and CFO attributes are measured by age, gender, professional degree, CPA designation, industry experience, total compensation, and tenure at current firm. I added CEO attributes, similar to the CFO attributes, as control variables to determine which officers' attributes contribute more to firm performance. 
Other control variables include profit, natural log of total assets, natural log of the firm's age, amount of leverage, tax rate of the firm, tangibility, and dividend.

\section{Sample}

My sample begins post-SOX, covering thirteen years from 2003 through 2016, and consists of all U.S. firms with available data. I obtained firms' financial data from the annual Compustat database, governance data from the BoardEx database, and salaries data from the Execucomp database. The final sample size for my main analysis was 88,694 observations. Firm-year observations with missing information was deleted. I ran the models with raw data; I also winsorized all continuous variables at the top and bottom one percentile of their distributions to normalize the data and confirm the results. The following section discusses the results.

\section{Results}

Descriptive Statistics

Table 1 presents the descriptive statistics for all the variables I used in this analysis. There are seven dependent variables used to measure firm performance, with the focus of the analysis being on both CC and OC. One of the most important functions of the CFO is cash management, but there are no direct connections linking successful firm performance by way of the CC or OC and specific characteristics directly attributable to the CFO. I included seven specific CFO characteristics; the same characteristics were included for the CEO as controls to determine which position contributes more to the success of the firm's performance. I also included seven firm performance control variables: profit, natural log of total assets, natural log of the firm's age, leverage, tax rate of the firm, tangibility, and dividend.

Table 2 presents the correlation among all the variables included in this analysis. The variables for CFO tenure and CFO industry experience were highly correlated as were total compensation for both CFO and CEO. However, after checking the variance inflation factor for each model and running collinearity diagnostics, there was no evidence of multicollinearity.

TABLE 1

\section{DESCRIPTIVE STATISTICS}

\begin{tabular}{lllllll}
\hline Variable & Observations & $\mathrm{M}$ & $\mathrm{SD}$ & $\mathrm{Q} 1$ & Median & $\mathrm{Q} 3$ \\
\hline CFOage & 3,506 & 48.889 & 11.957 & 45.000 & 51.000 & 55.000 \\
CFOgender & 3,506 & 0.095 & 0.293 & 0.000 & 0.000 & 0.000 \\
CFOprofdeg & 3,539 & 0.009 & 0.096 & 0.000 & 0.000 & 0.000 \\
CFOcpa & 3,539 & 0.036 & 0.187 & 0.000 & 0.000 & 0.000 \\
CFOindusexp & 3,536 & 1.425 & 0.810 & 0.693 & 1.386 & 2.079 \\
CFOtotcomp & 3,539 & 7.120 & 1.082 & 6.573 & 7.195 & 7.772 \\
CFOtenure & 3,539 & 1.571 & 0.844 & 1.099 & 1.609 & 2.197 \\
CEOage & 4,313 & 55.014 & 9.493 & 51.000 & 55.000 & 60.000 \\
CEOgender & 4,313 & 0.034 & 0.181 & 0.000 & 0.000 & 0.000 \\
CEOprofdeg & 4,332 & 0.014 & 0.116 & 0.000 & 0.000 & 0.000 \\
CEOcpa & 4,332 & 0.007 & 0.084 & 0.000 & 0.000 & 0.000 \\
CEOindusexp & 4,332 & 1.925 & 0.780 & 1.386 & 2.079 & 2.565 \\
CEOtotcomp & 2,563 & 8.261 & 0.964 & 7.636 & 8.344 & 8.922 \\
CEOtenure & 4,106 & 1.764 & 0.857 & 1.099 & 1.792 & 2.398 \\
cc & 53,895 & 2.179 & 1.196 & 1.633 & 2.264 & 2.837 \\
\hline
\end{tabular}




\begin{tabular}{lllllll}
\hline oc & 68,098 & 2.633 & 0.989 & 2.156 & 2.653 & 3.139 \\
roa & 87,281 & -5.257 & 472.698 & -0.154 & 0.015 & 0.063 \\
roe & 64,205 & -0.229 & 56.255 & -0.100 & 0.075 & 0.184 \\
acq & 83,090 & 0.982 & 1.897 & 0.000 & 0.000 & 0.974 \\
invest & 86,240 & 0.050 & 0.085 & 0.010 & 0.027 & 0.060 \\
costeqty & 54,832 & 14.366 & 38.888 & 0.436 & 9.309 & 27.308 \\
profit & 88,694 & -1.776 & 43.695 & -0.063 & 0.078 & 0.140 \\
lnassets & 88,694 & 5.542 & 2.784 & 3.539 & 5.635 & 7.552 \\
firmage & 76,491 & 2.484 & 0.928 & 1.946 & 2.565 & 3.135 \\
lev & 88,512 & 4.929 & 130.100 & 0.314 & 0.538 & 0.761 \\
taxrate & 71,597 & 0.049 & 6.068 & 0.000 & 0.044 & 0.172 \\
tangib & 88,196 & 0.259 & 0.268 & 0.044 & 0.151 & 0.419 \\
div & 88,694 & 0.000 & 0.012 & 0.000 & 0.000 & 0.000 \\
\hline
\end{tabular}




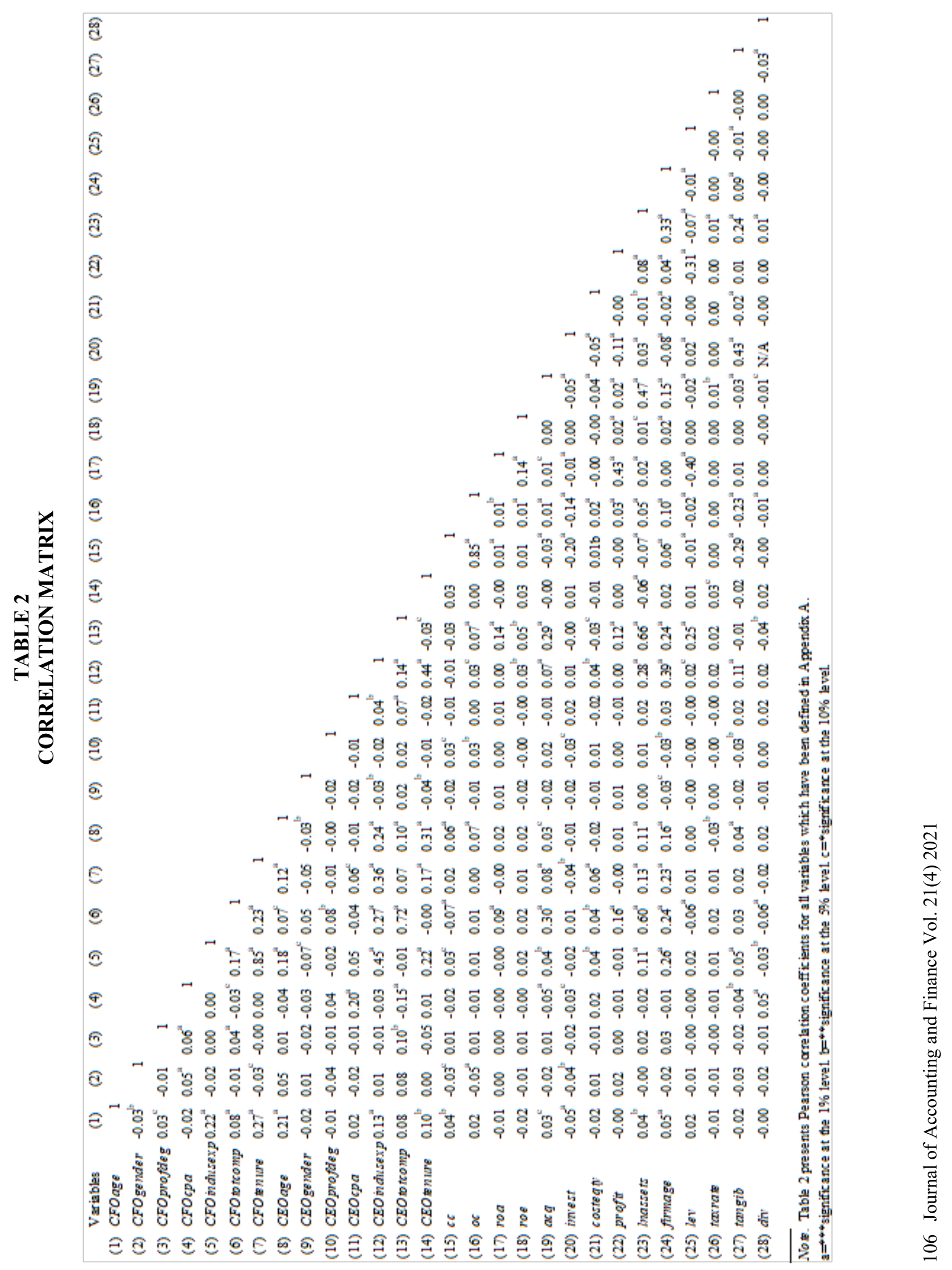


TABLE 3

THE RELATIONSHIP BETWEEN CHIEF FINANCIAL OFFICER AND CHIEF EXECUTIVE OFFICER CHARACTERISTICS AND FIRM PERFORMANCE MEASUREMENTS

\begin{tabular}{|c|c|c|c|c|c|c|c|}
\hline Variables & $\mathrm{cc}$ & oc & roa & roe & acq & invest & costeqty \\
\hline CEOage & $\begin{array}{l}0.006 \\
(0.005)\end{array}$ & $\begin{array}{l}0.003 \\
(0.003)\end{array}$ & $\begin{array}{l}0.000 \\
(0.001)\end{array}$ & $\begin{array}{l}0.007^{*} \\
(0.004)\end{array}$ & $\begin{array}{l}-0.009 \\
(0.012)\end{array}$ & $\begin{array}{l}0.000 \\
(0.000)\end{array}$ & $\begin{array}{l}0.064 \\
(0.126)\end{array}$ \\
\hline CFOprofdeg & $\begin{array}{l}0.105 \\
(0.144)\end{array}$ & $\begin{array}{l}0.130 \\
(0.081)\end{array}$ & $\begin{array}{l}0.008 \\
(0.017)\end{array}$ & $\begin{array}{l}0.296 \\
(0.207)\end{array}$ & $\begin{array}{l}1.156^{* * *} \\
(0.373)\end{array}$ & $\begin{array}{l}0.041 * * * \\
(0.014)\end{array}$ & $\begin{array}{l}-1.085 \\
(3.041)\end{array}$ \\
\hline CEOprofdeg & $\begin{array}{l}0.090 \\
(0.353)\end{array}$ & $\begin{array}{l}0.111 \\
(0.281)\end{array}$ & $\begin{array}{l}-0.059 \\
(0.066)\end{array}$ & $\begin{array}{l}-0.131 \\
(0.191)\end{array}$ & $\begin{array}{l}1.074 \\
(1.264)\end{array}$ & $\begin{array}{l}0.010^{*} \\
(0.005)\end{array}$ & $\begin{array}{l}-9.134 \\
(7.775)\end{array}$ \\
\hline CFOcpa & $\begin{array}{l}-0.124 \\
(0.355)\end{array}$ & $\begin{array}{l}-0.183 \\
(0.292)\end{array}$ & $\begin{array}{l}0.059 * * * \\
(0.022)\end{array}$ & $\begin{array}{l}0.366^{*} \\
(0.206)\end{array}$ & $\begin{array}{l}-0.362 \\
(0.635)\end{array}$ & $\begin{array}{l}-0.004 \\
(0.006)\end{array}$ & $\begin{array}{l}0.260 \\
(5.610)\end{array}$ \\
\hline CEOcpa & $\begin{array}{l}-0.024 \\
(0.239)\end{array}$ & $\begin{array}{l}0.246^{* *} \\
(0.123)\end{array}$ & $\begin{array}{l}0.023 \\
(0.033)\end{array}$ & $\begin{array}{l}0.031 \\
(0.075)\end{array}$ & $\dagger$ & $\begin{array}{l}-0.018^{* *} \\
(0.008)\end{array}$ & $\begin{array}{l}1.243 \\
(4.716)\end{array}$ \\
\hline CFOindusexp & $\begin{array}{l}-0.001 \\
(0.088)\end{array}$ & $\begin{array}{l}0.026 \\
(0.069)\end{array}$ & $\begin{array}{l}0.007 \\
(0.010)\end{array}$ & $\begin{array}{l}0.056 \\
(0.039)\end{array}$ & $\begin{array}{l}0.621 * * * \\
(0.204)\end{array}$ & $\begin{array}{l}-0.002 \\
(0.003)\end{array}$ & $\begin{array}{l}-5.262^{*} \\
(2.889)\end{array}$ \\
\hline CEOindusexp & $\begin{array}{l}0.169 * * \\
(0.075)\end{array}$ & $\begin{array}{l}0.096^{* *} \\
(0.042)\end{array}$ & $\begin{array}{l}-0.004 \\
(0.009)\end{array}$ & $\begin{array}{l}-0.046 \\
(0.049)\end{array}$ & $\begin{array}{l}-0.276^{*} \\
(0.159) \\
\end{array}$ & $\begin{array}{l}0.003 \\
(0.003)\end{array}$ & $\begin{array}{l}0.784 \\
(1.676)\end{array}$ \\
\hline \multicolumn{8}{|l|}{$\begin{array}{l}\text { Control } \\
\text { Variables }\end{array}$} \\
\hline profit & $\begin{array}{l}-0.314 \\
(0.489)\end{array}$ & $\begin{array}{l}-0.869^{* * *} \\
(0.284)\end{array}$ & $\begin{array}{l}0.389 * * * \\
(0.047)\end{array}$ & $\begin{array}{l}0.741 * * * \\
(0.056)\end{array}$ & $\begin{array}{l}.150 \\
(1.318)\end{array}$ & $\begin{array}{l}0.016^{*} \\
(0.010)\end{array}$ & $\begin{array}{l}-28.146 \\
(21.747)\end{array}$ \\
\hline lnassets & $\begin{array}{l}-0.125^{* * * *} \\
(0.035)\end{array}$ & $\begin{array}{l}0.007 \\
(0.021)\end{array}$ & $\begin{array}{l}0.011^{* *} \\
(0.004)\end{array}$ & $\begin{array}{l}0.030^{* *} \\
(0.014)\end{array}$ & $\begin{array}{l}0.675^{* * * *} \\
(0.086)\end{array}$ & $\begin{array}{l}-0.003^{* *} \\
(0.001)\end{array}$ & $\begin{array}{l}-0.540 \\
(0.836)\end{array}$ \\
\hline firmage & $\begin{array}{l}0.144^{*} \\
(0.076)\end{array}$ & $\begin{array}{l}0.057 \\
(0.049)\end{array}$ & $\begin{array}{l}-0.007 \\
(0.007)\end{array}$ & $\begin{array}{l}-0.017 \\
(0.042)\end{array}$ & $\begin{array}{l}-0.116 \\
(0.192)\end{array}$ & $\begin{array}{l}-0.002 \\
(0.003)\end{array}$ & $\begin{array}{l}-2.648 \\
(2.047)\end{array}$ \\
\hline lev & $\begin{array}{l}-0.445^{* * *} \\
(0.124)\end{array}$ & $\begin{array}{l}-0.192 * * \\
(0.079)\end{array}$ & $\begin{array}{l}-0.057^{*} \\
(0.032)\end{array}$ & $\begin{array}{l}-0.030 \\
(0.101)\end{array}$ & $\begin{array}{l}-0.377 \\
(0.493)\end{array}$ & $\begin{array}{l}-0.000 \\
(0.006)\end{array}$ & $\begin{array}{l}2.568 \\
(3.991)\end{array}$ \\
\hline taxrate & $\begin{array}{l}-0.070^{* * * *} \\
(0.023)\end{array}$ & $\begin{array}{l}0.018 \\
(0.064)\end{array}$ & $\begin{array}{l}0.001 \\
(0.006)\end{array}$ & $\begin{array}{l}-0.003 \\
(0.012)\end{array}$ & $\begin{array}{l}0.023 \\
(0.016)\end{array}$ & $\begin{array}{l}0.001 \\
(0.001)\end{array}$ & $\begin{array}{l}-0.968 * * * \\
(0.229)\end{array}$ \\
\hline tangib & $\begin{array}{l}-1.209^{* * *} \\
(0.280)\end{array}$ & $\begin{array}{l}-0.928^{* * *} \\
(0.183)\end{array}$ & $\begin{array}{l}-0.069 * * \\
(0.028)\end{array}$ & $\begin{array}{l}-0.314^{* * * *} \\
(0.121)\end{array}$ & $\begin{array}{l}-0.978^{*} \\
(0.586)\end{array}$ & $\begin{array}{l}0.129 * * * \\
(0.014)\end{array}$ & $\begin{array}{l}-1.627 \\
(5.656)\end{array}$ \\
\hline div & $\begin{array}{l}-14.099 \\
(16.128)\end{array}$ & $\begin{array}{l}20.671 \\
(13.459)\end{array}$ & $\begin{array}{l}-1.693 \\
(1.238)\end{array}$ & $\begin{array}{l}77.171^{*} \\
(42.834)\end{array}$ & $\begin{array}{l}0.000 \\
(0.000)\end{array}$ & $\begin{array}{l}0.000 \\
(0.000)\end{array}$ & $\begin{array}{l}-235.294 \\
(204.888)\end{array}$ \\
\hline Constant & $\begin{array}{l}2.828 * * * \\
(0.447)\end{array}$ & $\begin{array}{l}2.577 * * * \\
(0.307)\end{array}$ & $\begin{array}{l}-0.081 * * \\
(0.038)\end{array}$ & $\begin{array}{l}-0.390^{*} \\
(0.206)\end{array}$ & $\begin{array}{l}0.008 \\
(1.128)\end{array}$ & $\begin{array}{l}0.042 * * \\
(0.016)\end{array}$ & $\begin{array}{l}29.079 * * * \\
(9.643)\end{array}$ \\
\hline Industry FE & Yes & Yes & Yes & Yes & Yes & Yes & Yes \\
\hline Year FE & Yes & Yes & Yes & Yes & Yes & Yes & Yes \\
\hline Observations & 460 & 512 & 552 & 501 & 259 & 545 & 424 \\
\hline Adjusted $R^{2}$ & 0.206 & 0.173 & 0.486 & 0.284 & 0.306 & 0.570 & 0.344 \\
\hline
\end{tabular}

Note. This table reports estimation from ordinary least squares regression. I used both industry and year fixed effects. Also, I clustered standard errors by firm identification number (Gvkey). Robust standard errors were computed using the Huber-White sandwich estimator of variance by clustering on the firm level (Wolter, 2007). Variables are defined in Appendix A. $\dagger$ dropped by the model due to insufficient results.

${ }^{*} p<.1 .{ }^{* *} p<.05 . * * * p<.01$.

\section{Regression Analysis}

Table 3 reports the regression results for the CFO and CEO characteristics and firm performance analyses. In this section, I report the regression results and discuss the results of the relationship between $\mathrm{CFO}$ and $\mathrm{CEO}$ characteristics and the firm performance measures of success. 


\section{Chief Financial Officer Age}

The first hypothesis is that an older $\mathrm{CFO}$ will have both a lower $\mathrm{CC}$ and $\mathrm{OC}$, a higher ROA and ROE, more acquisitions, higher capital expenditures, and lower cost of equity. There were no significant results for CFO age with any of the performance measurements. Therefore, the first hypothesis was not supported.

The average age of CFOs in my study was 48.9 years; the average age of CEOs was 55 years. Both of these average ages seem rather young so the results that an older CFO will have both a lower CC and OC, a higher ROA and ROE, more acquisitions, higher capital expenditures, and lower cost of equity is not a big surprise.

Post-SOX, the role of the CFO is on the rise; however, the literature has not necessarily followed the same trajectory. First, the CEO continues to be the primary position for study. In addition, the variables I used seem to appear in more research that is being done in the accounting area as opposed to the area of finance. For example, Huang et al. (2012) reported on age and financial reporting quality. The same argument applies to Plöckinger et al. (2016) wherein they noted that older CEOs are less often involved in fraudulent (financial reporting) actions. Although it stands to reason that an older CFO brings more knowledge to the table, being older, more ethical, and conservative does not necessarily deliver on any of the aforementioned firm performance measures.

In other untabulated results, both the univariate regression analysis and a subsample multivariate regression analysis for CC and age revealed CEO age was statistically significant, but positive, at the 10\% level. This is not a surprise as the role of CEO requires a broader agenda that may necessitate a lower CC. Although none of the firm performance measures showed any significant results for CFO age, CEO age did have a positive and significant result for ROE.

\section{Chief Financial Officer Gender}

The second hypothesis is that a male CFO will have both a lower CC and OC, a higher ROA and ROE, more acquisitions, higher capital expenditures, and lower cost of equity. There were no significant results for CFO gender with any of the performance measurements. Therefore, the second hypothesis was not supported.

The finding of no significant results for CFO gender was a surprise. All the firm performance variables used to measure success in this study require decision-making as well as some level of risk assessment. Byrnes et al. (1999), Olsen and Cox (2001), and Plöckinger et al. (2016) reported that males are more likely to take risks than females, but this appears to be irrelevant. Huang and Kisgen's (2013) results may help explain. They reported that acquisitions made by firms with male executives have announcement returns approximately $2 \%$ lower than those made by firms with female executives; they surmised that male executives demonstrate overconfidence in their decision-making whereas female executives display more caution (Huang \& Kisgen, 2013). Laseter (2017) referred to overconfidence as hubris or dysfunctional confidence. That women display more caution may help to explain the results in untabulated results of subsample multivariate regression analyses, that is, $\mathrm{CC}$ was positive and significant for both $\mathrm{CFO}$ and CEO.

\section{Chief Financial Officer Professional Degree}

The third hypothesis is that a CFO with a professional degree will have both a lower $\mathrm{CC}$ and $\mathrm{OC}$, a higher ROA and ROE, more acquisitions, higher capital expenditures, and lower cost of equity. Two of the firm performance measures (acquisitions and investments) were statistically significant at $1 \%$. Investment was also positive and significant at $10 \%$ for CEO. Therefore, this hypothesis was partially supported.

As Plöckinger et al. (2016) noted, executives having an MBA degree tend to be more conservative in making their earnings forecasts, are more likely to disclose financial information, and report higher quality earnings. In addition, CFOs with an MBA degree or CPA certification are less often involved in restatements than CFOs without such degrees (Plöckinger et al., 2016). Once again, I will point out the expansive research on CEOs and (financial reporting) practices. Nonetheless, the business degree should prepare a CFO to make more strategic decisions with better results for these firm performance measures of success. 
In untabulated results, the ROE univariate regression analysis, for both CFO and CEO, was positive and significant at the $10 \%$ level. On the other hand, both $\mathrm{CC}$ and $\mathrm{OC}$ subsample regression analyses for CFO were significant but positive.

There may be another explanation for this. Chahyadi and Abusalim (2011) found that CFOs in large firms have different education characteristics than CFOs in medium-sized firms. Their results showed that large firms prefer CFOs with more general skills (that is, having an MBA) than CFOs with a Masters of Accounting or CPA certification (Chahyadi and Abusalim, 2011). This makes sense as a larger firm will use the C-suite members for more strategic decision-making whereas a smaller firm will need the CFO to perform (or more closely oversee) many of the treasury functions. To continue with that thought, I turn to the next hypothesis.

\section{Chief Financial Officer Certified Public Accountant Licensure}

The fourth hypothesis is that a CFO with a CPA designation will have both a lower CC and OC, a higher ROA and ROE, more acquisitions, higher capital expenditures, and lower cost of equity. For this CFO characteristic, the results indicated $1 \%$ significance for ROA and $10 \%$ significance for ROE. Therefore, this hypothesis was partially supported. These two commonly used ratios are utilized to measure a firm's strength and it is no surprise that these two financial ratios indicated success for a CFO.

In other untabulated results, the univariate regression analysis for ROA was also significant for the $\mathrm{CFO}$ at $5 \%$. In a subsample regression analysis for ROE, the results for CEO were statistically significant at $10 \%$. In two subsample regression analyses for OC, both results for $\mathrm{CFO}$ were negative and significant; on the other hand, the results for CEO were significant but positive. For both CFO and CEO, the results from the subsample regression analysis for investment were significant but negative. Although both a CFO and CEO with a CPA designation would be skilled to make investment decisions, sometimes investment decisions are made with overconfidence by the CEO, and CFOs take their direction from the CEO.

\section{Chief Financial Officer Industry Experience}

The fifth hypothesis is that a CFO with more industry experience will have both a lower CC and OC, a higher ROA and ROE, more acquisitions, higher capital expenditures, and lower cost of equity. The results showed acquisitions significant at $1 \%$ and cost of equity significant at $10 \%$. Therefore, this hypothesis was partially supported.

The untabulated results for the univariate regression analysis and other subsample regression analyses for acquisitions were also significant and positive for the CFO. The results for the CEO, however, were significant but negative.

In other untabulated results, the univariate regression analysis for ROE was significant and positive for CFO. The univariate regression analysis for cost of equity was significant and negative for the CFO. All $\mathrm{CC}$ and $\mathrm{OC}$ models for the $\mathrm{CEO}$ were significant and negative. Working capital management is a treasury function and although a CEO would be concerned about this, these metrics could get in the way of their decision-making; a more experienced CEO may well know exactly what kind of decisions can be made at the expense of $\mathrm{CC}$ and $\mathrm{OC}$.

\section{Chief Financial Officer Total Compensation}

For the hypothesis pertaining to a CFO with higher total compensation, there were insufficient observations; the sample size was reduced by almost $40 \%$. However, in untabulated results, both primary variables of interest (CC and OC) were statistically significant and negative for CFO. Similarly, OC was significant but negative for CEO.

\section{Chief Financial Officer Tenure at Current Position}

The last hypothesis is that a CFO with a long tenure at his or her current firm will have both a lower $\mathrm{CC}$ and $\mathrm{OC}$, a higher ROA and ROE, more acquisitions, higher capital expenditures, and lower cost of equity. There were no significant results for CFO tenure at current firm with any of the performance measurements. Therefore, this hypothesis was not supported. These results were surprising because it stands 
to reason that a CFO who has been in his or her position at a firm for a length of time would have success as measured by these firm performance metrics, but the surprise is tempered by the fact that the average tenure for CFOs in my sample was 1.5 years. The average tenure for CEOs in my sample was 1.8 years. In untabulated results, there is one significant result for CEO: ROE was positive and significant at $10 \%$.

\section{CONCLUSION}

The purpose of my study was to investigate the relationship between CFO attributes and determine whether there is some degree of firm success to be attained by the CFO. I used measures of financial firm performance, with a focus on $\mathrm{CC}$ and $\mathrm{OC}$, to proxy for success. In addition, I included the same characteristics for the CEO as control variables to test whether the CFO or CEO contributes more to the firm performance measures. My research showed that some, but not all, of the characteristics are associated with firm performance measures of success. Looking at both CFO and CEO characteristics, some of the variables were positive, some were negative, and some showed no relationship. Table 4 provides a summary of the study findings.

Overall, there were more statistically significant results for the CFO than for the CEO. Thus, the attributes of the CFO contribute more success to firm performance than do the attributes of the CEO. There were more variables included that do not have significance than variables that do have significance. Therefore, the analysis is not without limitations, which I will now address.

\section{Limitations of This Study}

The time frame for this analysis is considered somewhat of a short time period, especially since most of the variables can be obtained for a 30-year data set. A longer time period would enable an event study, pre- and post- SOX (circa 2002). Also, the addition of quarterly data should be included for another robustness check. There are additional accounting variables that could be added to the model, for example, involuntary restatements and the timeliness of disclosures.

\section{Suggestions for Future Research}

The position of CEO is primarily the focus of attention for researchers but post-SOX, the role of CFO is on the rise to a more critical level of importance due to the accountability expected from the person in that position. In a sense, this is a new strand of research and when the topic of interest is accounting and/or finance related, it would add value to include the position of CFO. There are other areas of research in which to study CFOs; for example, research on personality traits (overconfidence, pessimism, cognitive dissonance) could be added to this model. It would also be interesting to create an index of CFO characteristics and personality traits; this could possibly lead to the creation of a CFO profile. 


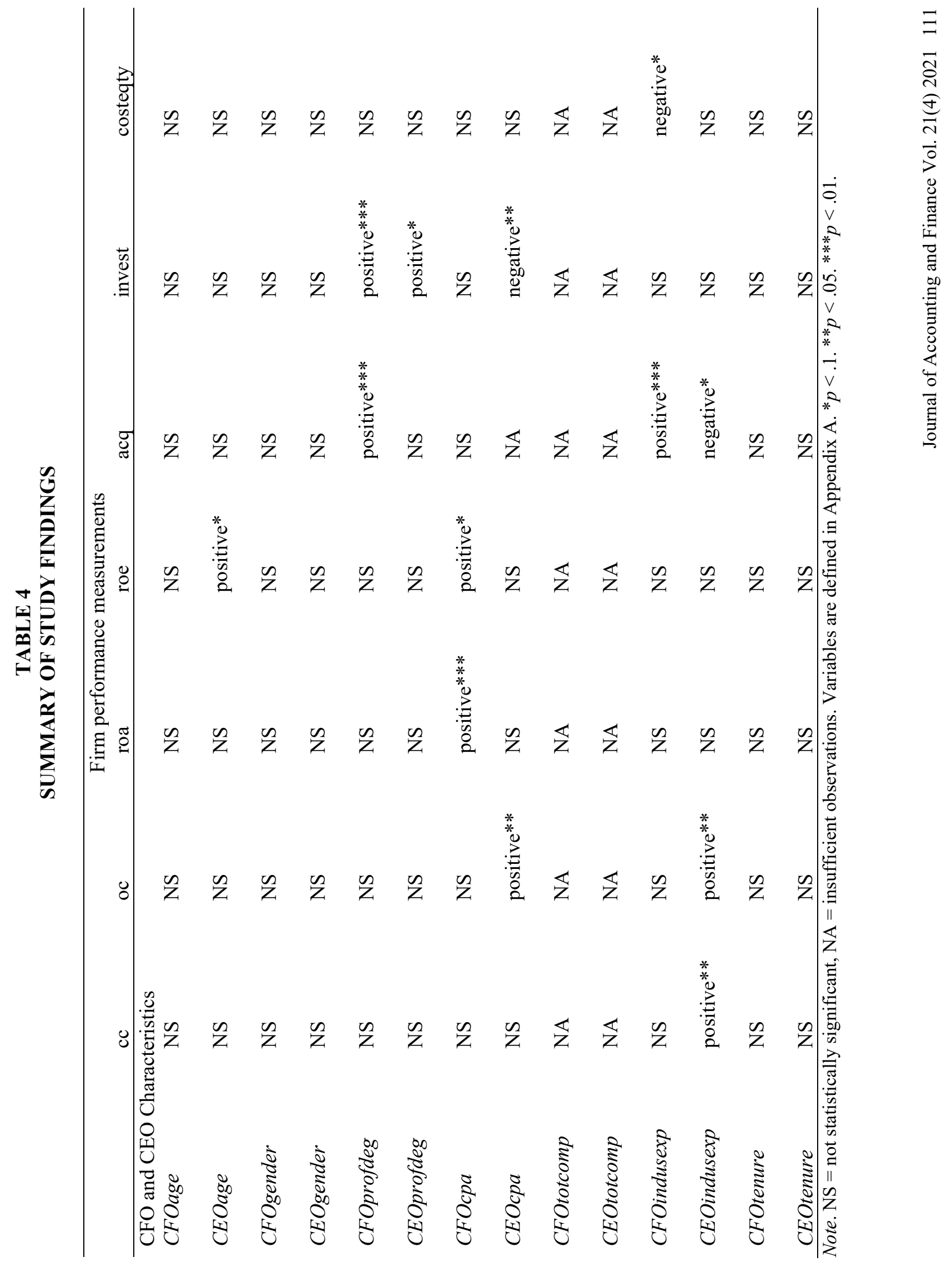




\section{REFERENCES}

Aier, J., Comprix, J., Gunlock, M., \& Lee, D. (2005). The financial expertise of CFOs and Accounting restatements. Accounting Horizons, 19(3), 123-135. https://doi.org/10.2308/acch.2005.19.3.123

Alkhafaji, A.F. (2007). Corporate governance: The evolution of the Sarbanes-Oxley act and its impact on corporate America. Competitiveness Review, 17(3), 193-202. https://doi.org/10.1108/10595420710833598

Allgood, S., \& Farrell, K.A. (2000). The effect of CEO tenure on the relation between firm performance and turnover. Journal of Financial Research, 23(3), 373-390. https://doi.org/10.1111/j.14756803.2000.tb00748.x

Balsam, S., Irani, A., \& Yin, Q. (2012). Impact of job complexity and performance on CFO compensation. Accounting Horizons, 26(3), 395-416. https://doi.org/10.2308/acch-50184

Banerjee, G., \& Kaya, H. (2016). Impact of firm characteristics and monetary policy environment on firms' profitability Ratios and price multiples: Evidence from U.S. industrial firms. Journal of Financial Management \& Analysis, 29(2), 1-9. https://doi.org/10.1016/j.jbankPn.2018.02.003

Barua, A., Davidson, L., Rama, D., \& Thiruvadi, S. (2010). CFO gender and accruals quality. Accounting Horizons, 24(1), 25-39. https://doi.org/10.2308/acch.2010.24.1.25

Baxter, J., \& Chua, W. (2008). Be(com)ing the chief financial officer of an organisation: Experimenting with Bourdieu's practice theory. Management Accounting Research, 19(3), 212-230. https://doi.org/10.1016/j.mar.2008.06.001

Beneda, N.L. (2003). Estimating free cash flows and valuing a growth company. Journal of Asset Management, 4(4), 247-257. https://doi.org/10.1057/palgrave.jam.2240106

Bourdieu, P. (R. Nice, Trans.). (1977). Outline of a Theory of Practice. Cambridge University Press, Cambridge. https://doi.org/10.1017/CBO9780511812507

Buchheit, S., Reitenga, A., Ruch, G., \& Street, D. (2019). Are CFOs effective operators? An empirical analysis of CFO/COO duality. Journal of Management Accounting Research, 31(2), 37-58. https://doi.org/10.2308/jmar-52168

Büttner, V., Schäffer, U., Strauss, E., \& Zander, K. (2013). A role-specific perspective on managerial succession: The case of new CFO origin. Schmalenbach Business Review, 65(4), 378-408. https://doi.org/10.1007/BF03396863

Byrnes, J., Miller, D., \& Schafer, W. (1999). Gender differences in risk taking: A meta-analysis. Psychological Bulletin, 125, 367-383. https://10.1037/0033-2909.125.3.367

Chahyadi, C., \& Abusalim, B. (2011). The role of education and experience in CFO career and compensation. Journal of Accounting and Finance, 11(3), 26-35. Retrieved from https://www.articlegateway.com/index.php/JAF/index

Cohen, B., \& Dean, T. (2005). Information asymmetry and investor valuation of IPOs: Top management team legitimacy as a capital market signal. Strategic Management Journal, 26(7), 683-690. https://doi.org/10.1002/smj.463

Datta, S., \& Iskandar-Datta, M. (2014). Upper-echelon executive human capital and compensation: Generalist vs specialist skills. Strategic Management Journal, 35(12), 1853-1866. https://doi.org/10.1002/smj.2267

Dikolli, S., Mayew, W., \& Nanda, D. (2014). CEO tenure and the performance-turnover relation. Review of Accounting Studies, 19(1), 281-327. https://doi.org/19.10.1007/s11142-013-9247-6

Duman, C., \& Sawathanon, S. (2009). Cash to cash cycle with a supply chain perspective (Thesis). Retrieved from https://www.diva-portal.org/smash/get/diva2:221367/FULLTEXT01.pdf

Elkhal, K. (2019). Business uncertainty and financial leverage: Should the firm double up on risk? Managerial Finance, 45(4), 536-544. https://doi.org. /10.1108/MF-10-2018-0491

Fama, E.F., \& Miller, M.H. (1972). The theory of finance. New York, NY: Holt, Rinehart E Winston.

Feng, M., Ge, W., Luo, S., \& Shevlin, T. (2011). Why do CFOs become involved in material accounting manipulations? Journal of Accounting and Economics, 51(1-2), 21-36. https://doi.org/10.1016/j.jacceco.2010.09.005

112 Journal of Accounting and Finance Vol. 21(4) 2021 
Filbeck, G., Krueger, T., \& Preece, D. (2007). CFO Magazine's “Working Capital Survey": Do selected firms work for shareholders? Quarterly Journal of Business and Economics, 46(2), 3-22. Retrieved from https://www.researchgate.net/journal/Quarterly-Journal-of-Business-andEconomics-0747-5535

Florackis, C., \& Sainani, S. (2018). How do chief financial officers influence corporate cash policies? Journal of Corporate Finance, 52, 168-191. https://doi.org/10.1016/j.jcorpfin.2018.08.001

Geiger, M., \& North, D. (2006). Does hiring a new CFO change things? An investigation of changes in discretionary accruals. Accounting Review, 81(4), 781-809. https://doi.org/10.2308/accr.2006.81.4.781

Gitman, L. (1974). Estimating corporate liquidity requirements: A simplified approach. Financial Review, 9(1), 79-88. https://doi.org/10.1111/j.1540-6288.1974.tb01453.x

Gitman, L., Moses, E., \& White, I. (1979). An assessment of corporate cash management practices. Financial Management, pp. 32-41. https://doi.org/10.2307/3665408

Granlund, M., \& Lukka, K. (1998). It's a small world of management accounting practices. Journal of Management Accounting Research, 10, 153-179. Retrieved from https://libproxy.uww.edu:9443/login?url=https://search-proquestcom.libproxy.uww.edu:9443/docview/210178088?accountid=14791

Grossman, W., \& Hoskisson, R.E. (1998). CEO pay at the crossroads of wall street and main: Toward the strategic design of executive compensation. The Academy of Management Executive, 12(1), $43-$ 57. https://doi.org/10.5465/ame.1998.254977

Groth, J.C. (1992). The operating cycle: Risk, return and opportunities. Management Decision, 30(4), 311. https://doi.org/10.1108/00251749210014725

Halpern, D. (1992). Sex differences in cognitive abilities (2nd ed.). https://doi.org/10.1016/S10416080(96)90003-5

Hambrick, D.C., \& Mason, P.A. (1984). Upper echelons: The organization as a reflection of its top managers. Academy of Management Review, 9(2), 193-206. https://doi.org/10.5465/amr.1984.4277628

Holden, R.T. (2005). The original management incentive schemes. The Journal of Economic Perspectives, 19(4), 135-144. https://doi.org/10.1257/089533005775196688

Huang, J., \& Kisgen, D. (2013). Gender and corporate finance: Are male executives overconfident relative to female executives? Journal of Financial Economics, 108(3), 822-839. https//doi.org/10.1016/j.jfineco.2012.12.005

Huang, H., Rose-Green, E., \& Lee, C. (2012). CEO age and financial reporting quality. Accounting Horizons, 26(4), 725-740. https://doi.org/10.2308/acch-50268

Hull, R.M. (2011). Debt-equity decision-making with and without growth. Managerial Finance, 37(8), 765-787. https://doi.org/10.1108/03074351111146210

Jalal, A., \& Khaksari, S. (2020). Cash cycle: A cross-country analysis. Financial Management, 49(3), 635-671. https://doi.org/10.1111/fima.12273

Jensen, M., \& Meckling, W. (1976). Theory of the firm: Managerial behavior, agency costs and ownership structure. Journal of Financial Economics, 3(4), 305-360. https://doi.org/10.1016/0304-405X(76)90026-X

John, C. (2001). A comparison of the current ratio and the cash conversion cycle in evaluating working capital cash flows (Doctoral dissertation, California Coast University). Retrieved from https://vtechworks.lib.vt.edu/bitstream/handle/10919/71545/270_1.pdf

Johnson, R., \& Soenen, L. (2003). Indicators of successful companies. European Management Journal, 21(3), 364-369. https://doi.org/10.1016/S0263-2373(03)00050-1

Kpodoh, B. (2010). Bankruptcy and financial distress prediction in the mobile telecom industry (Master's thesis). Retrieved from https://www.diva-portal.org/smash/get/diva2:832030/FULLTEXT01.pdf

Lai, R.K. (2006). Executive quirks in operational decisions. SSRN 815344. https://doi.org/10.2139/ssrn.815344 
Laseter, T. (2017). The line between confidence and hubris. Strategy+Business, 86. Retrieved from https://www.strategy-business.com/issue86-spring2017

Lopatta, K., Böttcher, K., \& Jaeschke, R. (2018). When labor representatives join supervisory boards: Empirical evidence of the relationship between the change to parity codetermination and working capital and operating cash flows. Journal of Business Economics, 88, 1-39. https://doi.org/10.1007/s11573-017-0860-x

Nourayi, M.M., \& Mintz, S.M. (2008). Tenure, firm's performance, and CEO's compensation. Managerial Finance, 34(8), 524-536. https://doi.org/10.1108/03074350810874055

Olsen, R., \& Cox, C. (2001). The influence of gender on the perception and response to investment risk: The case of professional investors. Journal of Psychology and Financial Markets, 2(1), 29-36. https://doi.org/10.1207/S15327760JPFM0201_3

O'Sullivan, K. (2004, June 18). CPA ascendant: With accounting savvy more important than ever, is the CPA the new must-have credential for finance execs? CFO Magazine. Retrieved from https://www.cfo.com/human-capital-careers/2004/06/cpa-ascendant/

Pagano, M., \& Stout, D. (2004). Calculating a firm's cost of capital. Management Accounting Quarterly, 5(3), 13-20. Retrieved from https://maaw.info/ManagementAccountingQuarterly.htm

Palombini, N.V.N., \& Nakamura, W.T. (2012). Key factors in working capital management in the Brazilian market. Revista de Administração de Empresas, 52(1), 55-69. https://doi.org/10.1590/S0034-75902012000100005

Pettus, M.L. (2006). Utilizing capabilities to increase stakeholder wealth: A balanced scorecard approach. Competition Forum, 4(1), 159-165. Retrieved from https://libproxy.uww.edu:9443/login?url=https://search-proquestcom.libproxy.uww.edu:9443/docview/214858767?accountid=14791

Plöckinger, M., Aschauer, E., Hiebl, M., \& Rohatschek, R. (2016). The influence of individual executives on corporate financial reporting: A review and outlook from the perspective of upper echelons theory. Journal of Accounting Literature, 37, 55-75. https://doi.org/10.1016/j.acclit.2016.09.002

Rambe, P., \& Mangara, T.B. (2016). Influence of integrated reporting ratings, CEO age, and years of experience on the share price of top 106 JSE listed companies. Problems and Perspectives in Management, 14(3), 216-231. https://doi.org/10.21511/ppm.14(3-1).2016.08

Richards, V.D., \& Laughlin, E.J. (1980). A cash conversion cycle approach to liquidity analysis. Financial Management, 9(1), 32-38. https://doi.org/10.2307/3665310

Rutgersson, C., \& Uddenberg, A. (2010). Growth made simple: How to grow a small company into a large corporation (Master's thesis). Retrieved from https://www.divaportal.org/smash/get/diva2:393160/FULLTEXT01.pdf

Schminke, M., Arnaud, A., \& Kuenzi, M. (2007). The power of ethical work climates. Organizational Dynamics, 36(2), 171-186. https://doi.org/10.1016/j.orgdyn.2007.03.005

Sellers, R.D., Fogarty, T.J., \& Parker, L.M. (2016). How important is the educational capital of chief financial officers? An examination of educational credentials in the context of other attributes. Global Perspectives on Accounting Education, 13, 1-19. Retrieved from https://cetl.kennesaw.edu/journals/global-perspectives-accounting-education

Spence, M. (1973). Job market signaling. The Quarterly Journal of Economics, 87(3), 355-374. https://doi.org/10.2307/1882010

Trent, R.J. (2019). The folly of financial myopia. Journal of Accounting and Finance, 19(1), 169-182. https://doi.org/10.33423/jaf.v19i1.1037

Wolter, K.M. (2007). Introduction to variance estimation. New York, NY: Springer.

Zhang, Y., \& Wiersema, M. (2009). Stock market reaction to CEO certification: The signaling role of CEO background. Strategic Management Journal, 30(7), 693-710. https://doi.org/10.1002/smj.772

Zorn, D. (2004). Here a chief, there a chief: The rise of the CFO in the American firm. American Sociological Review, 69(3), 345-364. https://doi.org/10.1177/000312240406900302 


\section{APPENDIX}

\section{Variable Definitions}

\begin{tabular}{|c|c|}
\hline Variable & Definition \\
\hline \multicolumn{2}{|l|}{$\mathrm{CFO} / \mathrm{CEO}$} \\
\hline \multicolumn{2}{|l|}{ Success } \\
\hline$c c$ & $\begin{array}{l}\text { Cash Cycle, days inventory outstanding plus days sales outstanding minus days } \\
\text { payable outstanding; }\end{array}$ \\
\hline$o c$ & Operating Cycle, sum of inventory cycle and receivable cycle; \\
\hline roa & Return on Assets, net income divided by assets; \\
\hline roe & Return on Equity, net income divided by shareholders' equity; \\
\hline$a c q$ & $\begin{array}{l}\text { Acquisitions, cash outflow of funds used for and/or the costs relating to acquisition } \\
\text { of a company in the current year or effects of an acquisition in a prior year carried } \\
\text { over to the current year; }\end{array}$ \\
\hline invest & Investments, capital expenditures divided by total assets; \\
\hline costeqty & $\begin{array}{l}\text { Cost of Equity, capital asset pricing model (CAPM), the equity structure of the } \\
\text { business; }\end{array}$ \\
\hline \multicolumn{2}{|l|}{ CFO Attributes } \\
\hline CFOage & CFO Age, current number of years old; \\
\hline CFOgender & CFO Gender, 0 = Male, $1=$ Female; \\
\hline CFOprofdeg & $\begin{array}{l}\text { CFO Professional Degree, } 0=\text { no professional degree, } 1=\text { professional degree } \\
(\mathrm{MBA}, \mathrm{JD}, \mathrm{MD}, \mathrm{PhD}) \text {; }\end{array}$ \\
\hline CFOcpa & CFO CPA, $0=$ does not have designation, $1=$ has designation; \\
\hline CFOindusexp & $\begin{array}{l}\text { CFO Industry Experience, number of years working in current industry, based on } \\
\text { SIC code; }\end{array}$ \\
\hline CFOtotcomp & CFO Total Compensation, salary, bonus, restricted stock, stock options; \\
\hline CFOtenure & CFO Tenure, number of years at current firm; \\
\hline \multicolumn{2}{|l|}{ CEO Attributes } \\
\hline CEOage & CEO Age, current number of years old; \\
\hline CEOgender & CEO Gender, 0 = Male, $1=$ Female: \\
\hline CEOprofdeg & $\begin{array}{l}\text { CEO Professional Degree, } 0=\text { no professional degree, } 1=\text { professional degree } \\
(\mathrm{MBA}, \mathrm{JD}, \mathrm{MD}, \mathrm{PhD}) ;\end{array}$ \\
\hline CEOcpa & CEO CPA, $0=$ does not have designation, $1=$ has designation; \\
\hline CEOindusexp & $\begin{array}{l}\text { CEO Industry Experience, number of years working in current industry, based on } \\
\text { SIC code; }\end{array}$ \\
\hline CEOtotcomp & CEO Total Compensation, salary, bonus, restricted stock, stock options; \\
\hline CEOtenure & CEO Tenure, number of years at current firm; \\
\hline
\end{tabular}


Variable

Control Variables

Profit

Lnassets

Firmage

Lev

Taxrate

Tangib

Div

\section{Definition}

Profit, operating profit before taxes and depreciation divided by total assets; ln Assets, natural log of Total Assets;

Firm Age, from date of initial public offering;

Leverage, total liabilities divided by total assets;

Tax Rate, income tax expenses divided by the earnings before taxes;

Tangibility, net property, plant, and equipment divided by total assets;

Dividend, cash dividends divided by total assets. 